\title{
THE INFLUENCE OF PERSONAL VALUE AND WORK MOTIVATION ON EMPLOYEE ENGAGEMENT IN GENERATION Y
}

\author{
Ramalaksana Made*, Sukmawati Anggraini, Hubeis Aida Vitayala S. \\ School of Business, Bogor Agricultural University, Indonesia \\ ${ }^{*}$ E-mail: made.ramalksn@gmail.com
}

\begin{abstract}
Generational differences is an issue that has not been widely studied in Indonesia. Data from BPS (statistics indonesia) showed that Generation $Y$ will be leading work force in the next few years. Generation $Y$ has different characteristic, work value, behaviour from former generations. The aim of this study to analyze personal value and work motivation on employee engagement in Generation Y. The study was conducted by online survey in Indonesia. The data of this study was collected through a questionnaire to 351 respondents of Generation Y. Structural Equation Modeling results showed that there is significant differences between personal value and work motivation, personal value and employee engagement, work motivation and employee engagement. The results showed employee engagement on Generation $Y$ can be increased by increasing work motivation and personal value.
\end{abstract}

\section{KEY WORDS}

Personal value, work motivation, generations, employee engagement.

In an organization the role of human resources is very important. Human Capital is one of the most important elements of a company's intangible assets (Baron et al. 2013). Employee engagement is a positive condition, fulfillment, and mental activity with courage characteristics (full of energy), dedication, and absorption (Schaufeli \& Bakker 2004). Employees, who are engaged, will be encouraged to do challenging goals. They have a desire for success and personal commitment to achieve that goal. Not only enterprising but also enthusiastic to use the energy that they have to work.

According to Ayu (2015) stated that personal resources is a variable that affects employee engagement. Personal resources are individual aspects that generally relate to the resilience and success of individuals to control the impact of the work environment (Hobfoll et al. 2003). There are many aspects of the individual that can affect how a person works some of them are value and motivation. Value is the basic concepts to describe the organization personally and socially as well as changes in the organization (Wibowo 2013). Value is a fundamental description of motivation (Parks \& Guay 2009). There is a conceptual correlation between the value and motivation that a person has. These differences between value and motivation can lead to a gap that has an impact on employee engagement.

Based on BPS (Statistics Indonesia) data of 2017 showed the total workforce of indonesian population is 131.544 .111 millions people. Now the work force is dominated by Generation $X$ of $43.28 \%$ of total work force population, while Generation $Y$ is $40.77 \%$ and Baby Boomers is $15.95 \%$ of total work force population. Based on the total Generation $Y$ number, there are $17.85 \%$ (15.234.991 millions people) who are in formal and non formal education, so if they complete their education then the next Generation $Y$ group will dominate the workforce in Indonesia (BPS 2017). Meanwhile, those Baby Boomers have entered retirement so the company will find new employees to replace them. Generation X will replace Baby Boomers and take over the role of leadership in the company. Therefore, as a leader Generation X must prepare to work with Generation $Y$, where Generation $Y$ has great potential as a company asset, but it takes time to get to know Generation $Y$.

Both Generation $X$ and Generation $Y$ have different characteristics, beliefs, work ethics, values, behaviors, and work expectations in performing their functions in a company (Niemiec 2000). According to Jorgensen (2015) stated that there are differences in the way 
of view between these two generations. Generation $X$ prefers to work independently and gain authority in doing their work, whereas Generation $Y$ prefers to work by following technology and getting information about their work. Gursoy et al. (2008) stated that Generation Y has a high loyalty to an idea than a company. Srinivasan (2012) stated that Generation $Y$ is a generation that wants a freedom. This generation will ask the cause why it has to do something in a certain way. Doing a job as quickly as possible with a variety of alternative ways of using technology. Therefore, it is necessary to conduct further research on Generation $Y$. The purpose of this study is to analyze the effect of personal value on employee engagement in Generation $Y$, to analyze the effect of personal value on work motivation on Generation $Y$, to analyze the effect of work motivation on employee engagement on Generation $Y$ and how strategies to improve employee engagement.

\section{LITERATURE REVIEW}

A basic understanding of the classification of generations is the premise that generation is a group of individuals affected by historical events and cultural phenomena occurring and experienced in their phases of life (Twenge 2006, Nobel \& Schewe 2003) and their occurrence and phenomena led to the formation of collective memory which affects their lives. Based on this, there are two things that underlie the generation grouping, namely demographic factors especially birth year and sociological factors in particular are historical events (Son 2016).

Wibowo (2013) explained that motivation is the stimulus for acting against a sequence of human behavior processes by considering direction, intensity, and persistence in achieving goals. Value is basic concepts in social research. Value is crucial factor to explain the organization not only personally or socially but also changes in the organization. Value also plays an important role not only in sociology but also in psychology, anthropology and other social sciences. Value is used to characterize the changing patterns of individuals, groups and communities and it is used to explain attitudes and behaviors based on motivation. Schwartz value inventory theory defines the value theory into ten values that arise based on the underlying motivation.

Value is grouped into four sections: Self-Transcendence, Conservation, SelfEnhancement, and Openness to Change. Each group contains different values. SelfTranscendence consists of 2 values such as universalism is a value that contains attitudes of understanding, appreciation, tolerance, protection for common prosperity; benevolence is an attitude in preserving and improving the welfare of relationships between people who often make personal contact. Conservation consists of 3 values such as security is harmony with society environment and self; conformity is the ability to refrain from interfering with others and violating existing norms; tradition is the respect, commitment and acceptance of ideas given by other religions or cultures. Self-Enhancement consists of 3 values such as power is a social and prestige status; achievement of personal success by demonstrating competence according to social standards, hedonism is pleasure or satisfaction for you. Openness to Change consists of stimulation of joy, novelty and kinship in life; Self-direction is an independent thinking in creating, choosing, and deciding a thing (Schwartz 1994).

According to Wahjosumido (1994) stated that motivation is a psychological process that reflects the interaction between attitudes, needs, perceptions, and decisions that occur in a person. Another notion given by Robbins and Coulter (2005) says that motivation is the willingness to do high-level business to achieve organizational goals conditioned by the ability of these businesses satisfy the needs of the number of individuals. Motivation according to Mangkuprawira \& Hubeis (2007) is the stimulus that makes employees achieves certain goals.

The latest theory about motivation is a theory developed by Twenge et al. (2010), Twenge stated that work motivation can be divided into five factors, there is extrinsic, intrinsic, leisure, social, and altruistic motivator. Extrinsic work motivators are real rewards such as compensation, promotion and status opportunities. Intrinsic work motivator is a tangible reward that causes a person to be motivated in work. Leisure work motivator is an 
award that allows work life balance such as flexibility of working hours, free from supervision. Social work motivator is an emotional reward that satisfies the need to connect with others (interpersonal). Altruistic work motivator is a tangible reward for satisfying the needs of helping others directly (Twenge et al. 2010).

The concept of employee engagement is a new concept that emerged over the past two decades. Employee engagement is the development of two previous concepts of commitment and organizational citizenship behavior (OCB). The concept of employee engagement is different from the previous concept because this concept is including the element of business awareness. Employee engagement also shows more mutual giving and receiving relationships between employees and companies. (Robinson, Perryman, Haydday 2004). Schaufeli and Bakker (2004) defined employee engagement as a positive, satisfying, job-related attitude characterized by vigor, dedication, and absorption, which refers to the state of true and consistent feelings and thoughts that not just focus on a particular object, event, individual or behavior. There are 3 aspects in forming engagement that are:

- Vigor, characterized by high levels of strength and mental resilience in work, a willingness to strive earnestly in the work and persistent in the face of adversity;

- Dedication, characterized by a feeling that is full of meaning, enthusiasm, inspiration, pride and challenge;

- Absorption, characterized by full concentration and an intense interest in the work, time passes so fast and difficult individual escape from work.

Employee engagement is categorized in the concept of motivation. The employee feels engaged, and then he will be compelled to do challenging goals. They have a desire for success and personal commitment to achieve that goal. Employees who are engaged not only enterprising but also enthusiastic to use the energy they have to work. Research showed that there is a positive relationship between employee engagement and organizational commitment (Demerouti et al. 2001), which will have an impact on employee performance (Kahn 1990). It is important for managers to strengthen engagement, since non-engaged employees become a problem where workers lose commitment and motivation (Aktouf 1992).

\section{METHODS OF RESEARCH}

The research was conducted by online survey from January to March 2018 in Indonesian territory. The sampling technique used in this research is the convenience sampling technique. Researchers used Generation $Y$ aged 18-36 years (Strauss \& Howe 2000) who were working as research samples. According to (Ferdinand 2002) the determination of the number of samples in the study using SEM is 5-10 times of the research indicators. Indicator for this research is 56 indicators, so this research obtained 351 respondents of Generation Y. Data collection is using a questionnaire by spreading through social media. The questionnaire consists of 4 sections. The first section is the biodata of respondents. The second section consists of 21 indicators that reflect personal value based on SVI (Schwartz Value Inventory). The third section consists of 18 indicators that reflect work motivation according to Twenge et al. (2010). The fourth section consists of 17 indicators that describe employee engagement based on Utrecht Work Engagement (Schaufeli \& Bakker 2004).

Data collected using likert scale, second and third part of questionnaire using measurement scale 5 (strongly disagree, disagree, neutral, agree, strongly agree) and fourth part of questionnaire using measurement scale 7 (Never, almost never, rarely, sometimes, often, very often, always). The analytical technique in this research tested by using structural equation model. The structural equation model (SEM) is a statistical technique that allows testing of a relatively complex set of relationships simultaneously. The results of these analyzes used as the basis for recommendations of organization on employee engagement. The recommendations were also based on literature studies related to research. The conceptual framework of this research can be seen in Figure 1. 


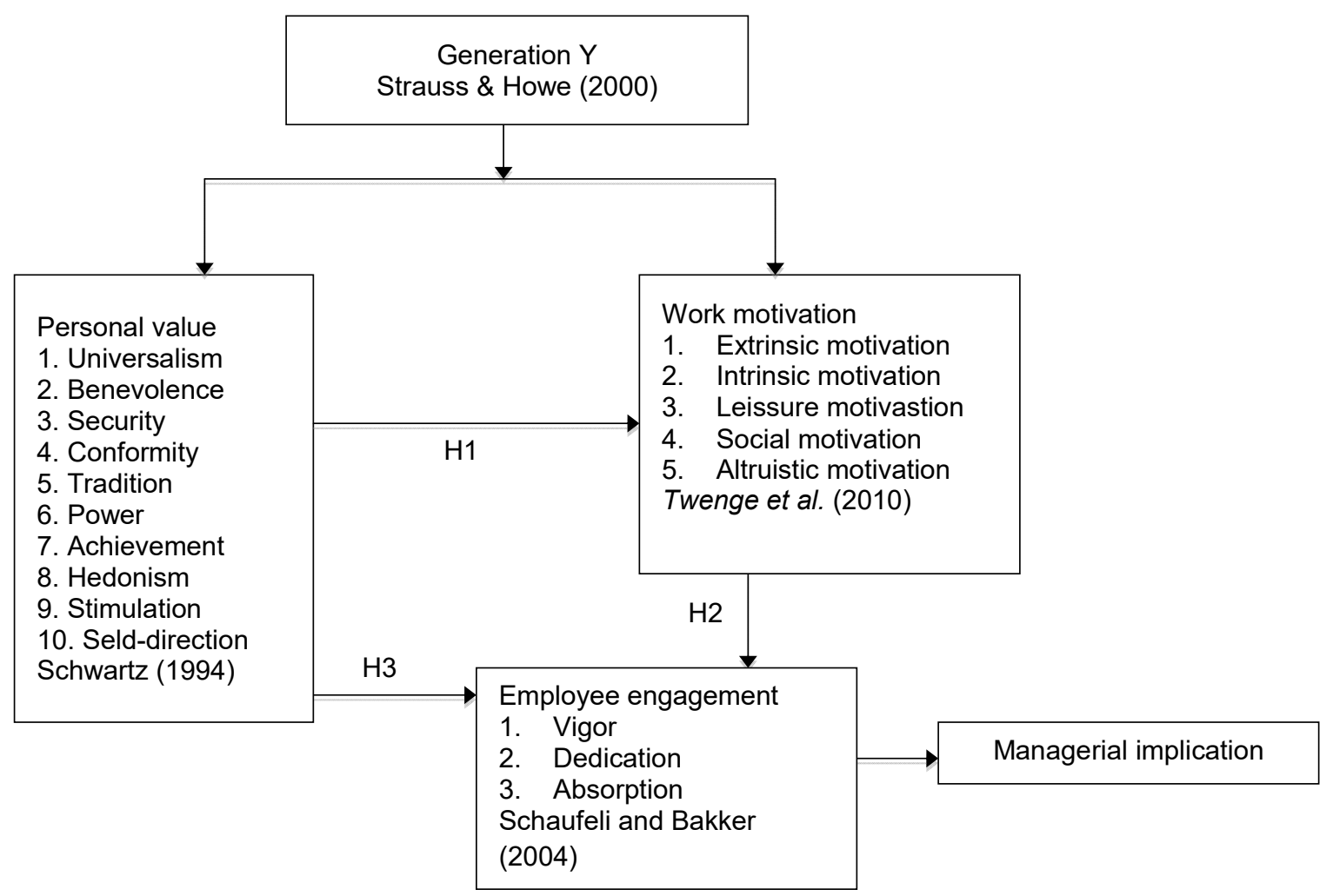

Figure 1 - Conceptual Framework of the Research

Based on the conceptual framework above, the proposed research hypotheses are:

$\mathrm{H}_{1}$ : The personal value has a positive and significant effect on work motivation;

$\mathrm{H}_{2}$ : The work motivation has a positive and significant effect on employee engagement;

$\mathrm{H}_{3}$ : The personal value has a positive and significant effect on employee engagement.

\section{RESULTS AND DISCUSSION}

Table 1 showed the profile of 351 respondents. The respondents in this research are $56.4 \%$ women and $43.6 \%$ men. It was not obtained intentionally, because in the acquisition of respondents there is no difference of gender. Based on marital status $76.4 \%$ respondents are single and $23.6 \%$ respondents have been married. In line with BKN that average age of Indonesians married at 25 years (BKKBN 2013).

Table 1 - Respondent characteristic of Generation $Y$

\begin{tabular}{llll}
\hline Variable & Description & Frequency & Percent (\%) \\
\hline Gender & Male & 153 & 43.6 \\
& Female & 198 & 56.4 \\
\hline Marital status & Single & 268 & 76.4 \\
& Married & 83 & 23.6 \\
\hline Education & Senior high school & 23 & 6.6 \\
& Diploma & 30 & 8.5 \\
& Undergraduate & 264 & 75.2 \\
& Postgraduate & 33 & 9.4 \\
& Doctorate & 1 & 0.3 \\
\hline Occupation & Government employee & 27 & 7.7 \\
& BUMN employee & 30 & 8.5 \\
& Private employee & 285 & 81.2 \\
& Entrepreneur & 3 & 0.9 \\
& Others & 6 & 1.7 \\
\hline
\end{tabular}


The respondents at the last level of undergraduate education dominate about $75.2 \%$ of total respondents. Respondents with postgraduate education level followed by a percentage of $9.4 \%$. And the respondents with the last education senior high school and diploma were $6.6 \%$ and $8.5 \%$. This suggests that Generaton $Y$ concern about their education because on second row occupied by postgraduate and a person already has doctorate degree. Table 1 also showed the distribution of respondents by profession dominated by private employee groups then others group. Due to Generation $Y$ characteristic, this generation prefer dynamic environment in workplace.

Based on result of SEM processing evaluation model with chi-squre value equal to 94.21 while chi-square table is 97.35 , this condition means that chi-square criterion fulfilled (good fit) with p-value equal to 0.077 . Criteria RMSEA has a value of 0.026 which means smaller than 0.08 so this model can define as a good fit. Table 2 showed some of the criteria that indicate a good model. Almost all criteria show that the model is a good model, so this model is used in this research.

Table 2 - The value of SEM model test

\begin{tabular}{cccc}
\hline Goodness of fit index & Cut-off Value & Hasil & Kesimpulan \\
\hline Chi-square & $\leq 97.35$ & 94.21 & Fit \\
Sign probability & $\geq 0.05$ & 0.076 & Fit \\
df & $\geq 0$ & 76.0 & Fit \\
GFI & $\geq 0.90$ & 0.97 & Fit \\
AGFI & $\geq 0.90$ & 0.95 & Fit \\
CFI & $\geq 0.90$ & 0.99 & Fit \\
TLI/NNFI & $\geq 0.90$ & 0.99 & Fit \\
NFI & $\geq 0.90$ & 0.97 & Fit \\
IFI & $\geq 0.90$ & 0.99 & Fit \\
RMSEA & $\leq 0.08$ & 0.026 & Fit \\
RMR & $\leq 0.05$ & 0.015 & Fit \\
\hline
\end{tabular}

Figure 2 showed loading factors between latent variables between personal value and work motivation have good criteria, while the relationship between personal value variable and work motivation variable have low relationship with employee engagement but have positive influence. Loading factor indicates good criteria when the value is above 0.5 (Wijayanto 2008).

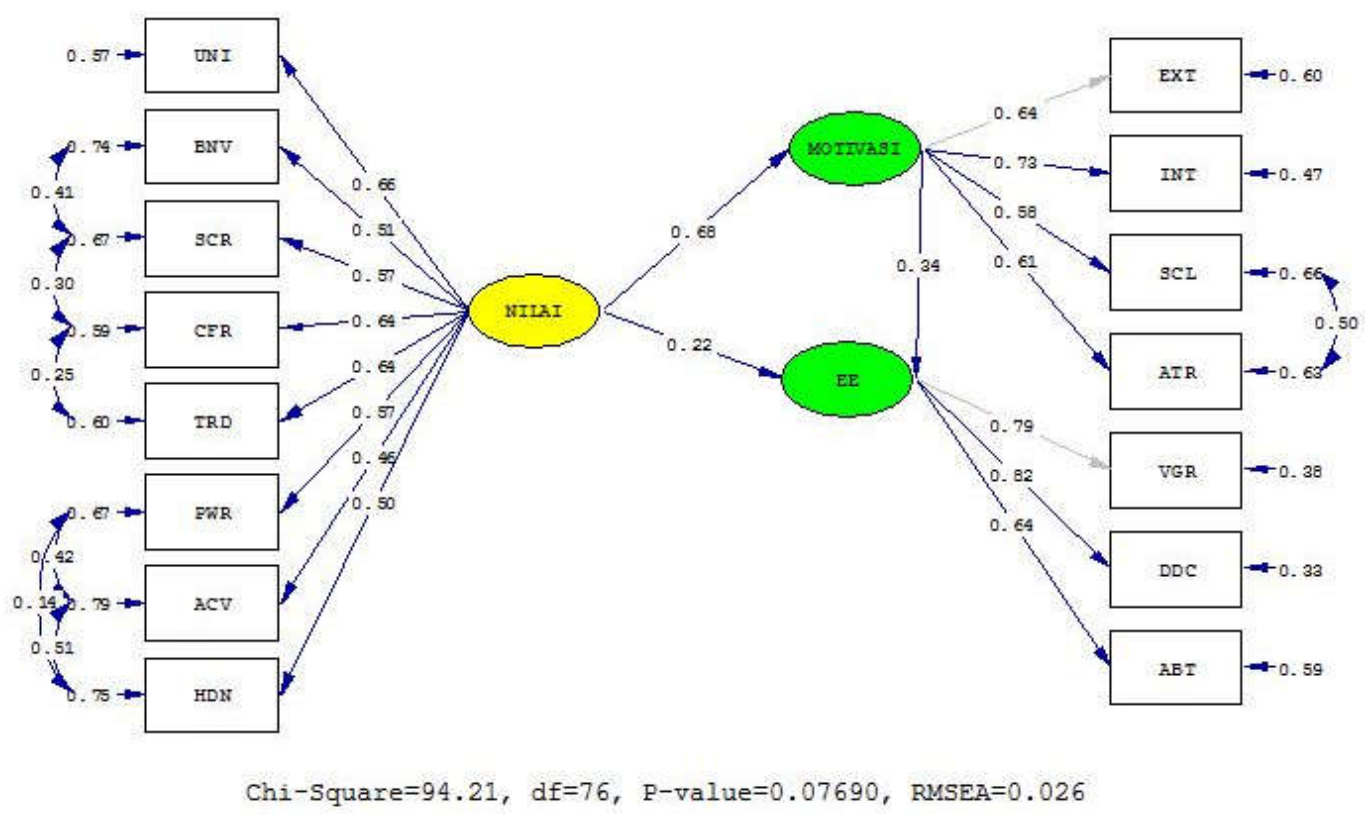

Figure 2 - The value of loading factor model of the influence of personal value and work motivation on employee engagement in Generation $Y$ 
The power indicator has a low charge value but the model criteria are categorized as a good model so this indicator remains listed in model. Indicators of stimulation and selfdirection have loading factor below 0.5 so these indicators not listed in model. Work motivation has a good loading factor value but extrinsic indicator does not have an effect while the leisure factor has loading factor below than 0.5 . In employee engagement variable, vigor indicator is not influenced by other variables while dedication and absorption have a loading factor above 0.5 .

Universalism indicator becomes the biggest indicator affecting personal value $(0.66)$. Generation $Y$ is a generation which is viewing a lot of value in their lives. Ismail (2016) stated that Generation $Y$ views strongly universal values compared to other generations. According to Ismail \& Hoo (2014), individuals who exhibited a greater tendency to develop the challenging personal career goals. At work motivation intrinsic indicator becomes the biggest indicator that influence work motivation (0.73). The dedication indicator becomes the largest factor that affects employee engagement $(0.82)$. Generation $\mathrm{Y}$ is a generation which is more loyal to their idea than a company, so this generation assesses intrinsic motivation higher than other generations (Gursoy et al. 2008).

The second evaluation was performed with $t$ test statistic with standard $t$ table at least 1.96. $T$ value of this table is obtained by using error rate $(\alpha)$ of $5 \%$. Based on the resulted of $t$ test (Figure 3 ) the personal value of work motivation is 8.13 with the loading factor of 0.68 , the personal value to the employee engagement is 2.03 with the loading factor 0.22 , the work motivation towards employee engagement is 3.07 with the loading factor of 0.34 can be concluded that $\mathrm{H}_{0}$ is rejected ( $\mathrm{t}$ count $>\mathrm{t}$ table or $-\mathrm{t}$ arithmetic <-t table).

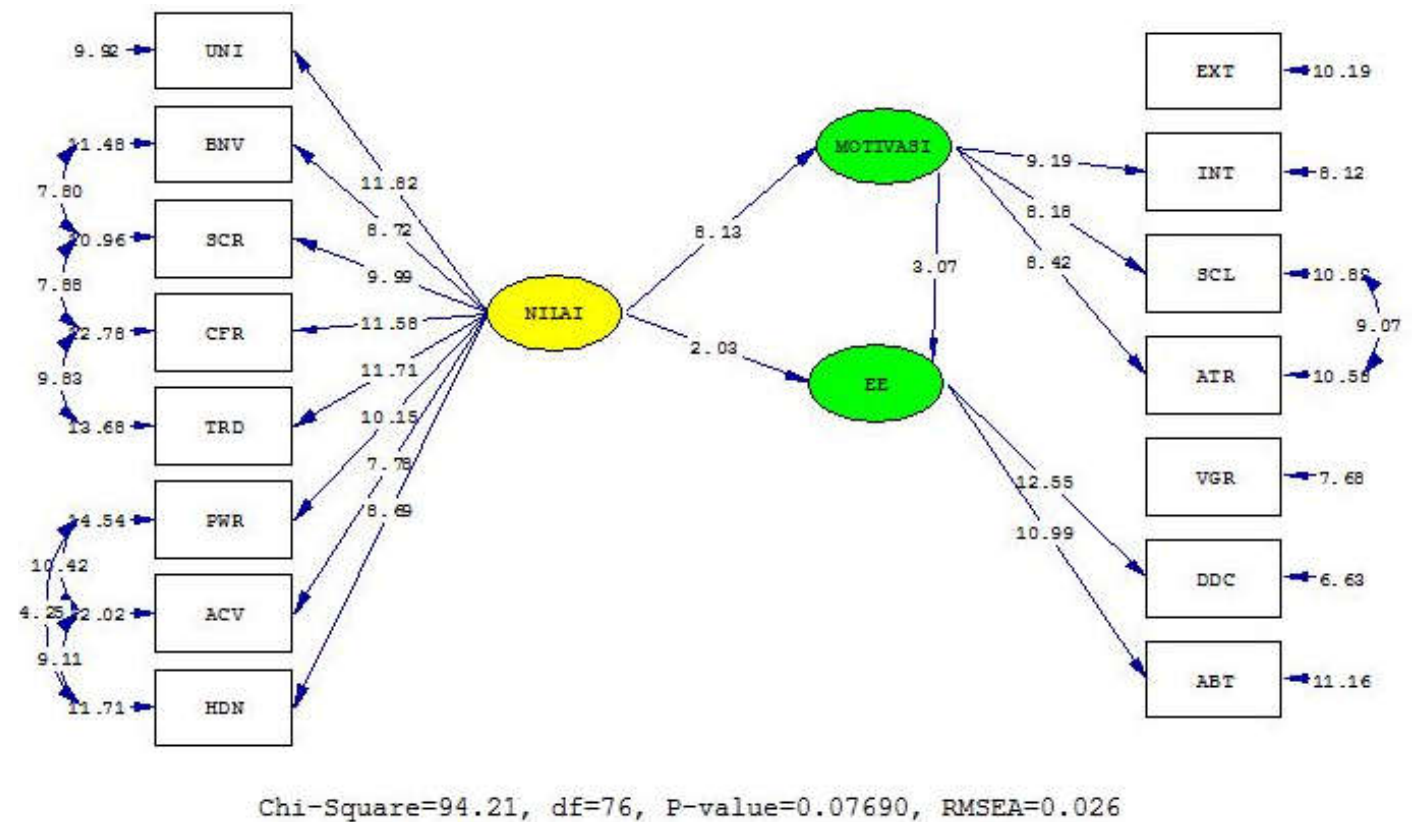

Figure 3 - The value of t-test model of the influence of personal value and work motivation on employee engagement in Generation $Y$

Statistical test conducted using SEM found that three variables have a positive and significant relationship. Hypothesis testing showed three research hypotheses accepted can be seen in Table 3.

Table 3 - Conclusions of hypothesis

\begin{tabular}{lllll}
\hline & Loading factor & T-statistic & T-table $(\alpha=5 \%)$ & Conclutions \\
\hline Personal value -> work motivation & 0.68 & 8.13 & 1.96 & $\mathrm{H}_{1}$ accepted \\
Work motivation-> employee engagement & 0.34 & 3.07 & 1.96 & $\mathrm{H}_{2}$ accepted \\
Personal value-> employee engagement & 0.22 & 2.03 & 1.96 & $\mathrm{H}_{3}$ accepted \\
\hline
\end{tabular}


Personal value affects work motivation significantly positive at the $5 \%$ level. Value is crucial factor to explain the organization not only personally or socially but also changes in the organization. Value is used to characterize the changing patterns of individuals, groups and communities and it is used to explain attitudes and behaviors based on motivation (Wibowo 2013). Generation Y views value in personal value influences their work motivation. Personal value has a significant effect on employee engagement also at $5 \%$ level. Universalism is the attitude of a person in assessing social welfare in society consists of the value of being broadminded, social justice, racial and gender equality, world at peace, world of beauty, unity with nature, wisdom, protecting the environment. This value also contributes to inner harmony and having a spiritual life (Sagiv \& Schwartz 1995). Benevolence was positively related to organizational and occupational commitment (Cohen 2010).

Security indicator provides employees with security (protection of stability) in terms of social support will lead employees to feel more secure in their jobs (Ismail 2016). Conformity consists of the values of loyal and responsible. Conformity was positively related to organizational and occupational commitment of employees (Cohen 2010). Gen-Y has not only sought fulfillment and bring a full integration of work-life balance but also valued tradition as well. Power indicators relate to political behavior based on motivation to control resources. There is a positive relationship between the achievement and other personal and cultural indicators in particular with power (Feather 1998; Wigfield \& Eccles 1994). Hedonism is believed to contribute to happiness by its positive effect on the physical health of an individual (Warburton \& Sherwood 1996). It facilitates one's performance (Veenhoven 2003), which inevitably involves careers.

Work motivation has a significant effect on employee engagement at the level of $5 \%$ in line with research conducted by (Rachmatullah et al., 2015). Employee engagement is categorized in the concept of motivation. Employees who are engaged not only enterprising but also enthusiastic to use the energy they have to work. Research showed that there is a positive relationship between employee engagement and organizational commitment (Demerouti et al. 2001), which will have an impact on employee performance (Kahn 1990). It is important for managers to strengthen engagement, since non-engaged employees become a problem where workers lose commitment and motivation (Aktouf 1992).

Based on analysis results effect of personal value and work motivation on employee engagement, employee engagement can be improved through personal value and work motivation. Several ways that can be done to improve employee engagement as follows:

- Based on work motivation employee engagement can be improved by holding training to increase the ability of individuals in addition to corporate training another training can be done to provide space for employees to make them become more creative. The company also needs to organize social events involving all employees and companies need to improve further CSR programs.

- Company must implement a good two-way communication system. Good two-way communication is happening between the boss and subordinates, so that subordinates have space to express their opinions. Not only that but good two-way communication also implements a confirmation system that anything involving decision-making should be confirmed by superiors and subordinates.

\section{CONCLUSION}

The conclusion of this study is employee engagement is influenced by work motivation and employee engagement is also influenced directly or indirectly by personal values significantly and positively in Generation Y. Generation $\mathrm{Y}$ assesses the universalism indicator of the personal variable has the greatest influence. In work motivation variable, intrinsic indicator is the biggest influence whereas in employee engagement dedication variable become the biggest influence. Enhancement in employee engagement can be done by training to increase the ability of individuals and also corporate training can also provide space for employees to make them become more creative. 


\section{RECOMMENDATIONS}

Generation $Y$ is a younger generation who are more concerned with the convenience of work and life balance work, today many start-up businesses that emerge by recruiting this generation so it needs to do further research on the influence of the workplace of this generation, because start-up business is covering smart office concept. Further research can apply FGD method (focus group discussion) and interview to know deeper about generation characteristics.

\section{REFERENCES}

1. [BKKBN]. Badan Kependudukan and Keluarga Berencana Nasional. 2017. Usia pernikahan ideal 21-25 tahun. [diakses pada tanggal 8 Mei 2018].

2. [BPS] Badan Pusat Statistik. 2017. Jumlah angkatan kerja diatas usia 15 tahun. [diakses 10 Desember 2017].

3. Ayu DR. 2015. Pengaruh job demands, job resources, and personal resources terhadap work engagement. [Tesis]. Bogor (ID): Institut Pertanian Bogor.

4. Aktouf O. 1992. Management and theories of organizations in the 1990s: toward a critical radical humanism. Academy of Management Review 17:407- 431.

5. Baron A, Michael A. 2013. Human Capital Management: Achieving Added Value Through People. Terjemahan Lilian Juwono. Jakarta (ID): PPM.

6. Cohen A. 2010. Values and commitment: A test of Schwartz's human values theory among Arab teachers in Israel. Journal of Applied Social Psychology. 40(8):19211947.

7. Demerouti E, Bakker AB, De Jonge J, Janssen PPM, Schaufeli WB. 2001. Burnoutand engagement at work as a function of demands and control. Scandinavian Journal of Work Environment and Health 27:279-286.

8. Feather NT. 1998. Attitudes toward high achievers, self-esteem, and value priorities for Australian, American, and Canadian students. Journal of Cross-Cultural Psychology. 29(6):749-759.

9. Ferdinand A. 2002. Structural Equation Modelling dalam Penelitian Manajemen. Semarang (ID): UNDIP.

10. Gursoy D, Chi CG, Karadag E. 2013. Generational differences in work values and attitudes among frontline and service contact employees. International Journal of Hospitality Management. 32: 40-48

11. Hobfoll SE. 2002. Social and psychological resources and adaptation. Review of General Psychology. 6:307-324.

12. Ismail M. 2016. Cultural values and career goal of gen-x and gen-y : a conceptual framework. Global Business and Management Research: An International Journal. 8(2): 1-18.

13. Ismail M., 2014. Cultural values and career goals of the millennial generation: integrated conceptual framework. Journal of International Management Studies. 9(1):38-49.

14. Jorgensen B. 2003. Baby Boomers, Generation X and Generation Y: Policy implications for defence forces in the modern era. Foresight. 5(4):41-49.

15. Kaminakis K, Karantinou K, Boukis A. 2014. The mediating role of self-concept discrepancy in the relationship between values and personal based motivation of luxury products consumers [Disertasi]. Bandung (ID): Universitas Pendidikan Indonesia.

16. Kahn WA. 1990. Psychological conditions of personal engagement and disengagement at work. Academy of Management Journal 33:692-724.

17. Kuvaas B, Buch R, Weibel A, Dysvik A, Nerstad CGL. 2017. Do instrinsic and extrinsic motivation relate to employee outcomes. Journal of Economic Psychology: 1-47.

18. Lim HL. 2012. Atrracting and retaining Generation $Y$ engineering and business professionals in the Middle-east. Procedia-Social and Behavioral Sciences. 62:25-29.

19. Mangkuprawira S, Hubeis AV. 2007. Manajemen Mutu Sumber Daya Manusia. Bogor (ID): Ghalia Indonesia. 
20. Niemiec S. 2000. Finding common ground for all ages. SDM: Security Distributing \& Marketing. 30(3):81.

21. Noble SM, Schewe CD. 2003. Cohort segmentation: An exploration of its validity. Journal of Business Research. 56(12): 979-987.

22. Pan X, Mao T, Zhang J, Wang J, Pan Su. 2017. Psychological capital mediates the association between nurses practice environment and work engagement among chinese male nurses. International Journal of Nursing Sciences.

23. Parks L, Guay RP. 2009. Personality, values, and motivation. Personality and Individual Differences. 47:675-684

24. Rachmatullah A, Susanty AI, Partono A. 2015. Pengaruh motivasi terhadap employee engagement (Studi kasus di PT. House The House Bandung). E-Proceeding of Management 2(3): 2919-2927.

25. Robbins SP, Coulter M. 2005. Manajemen Jilid 2. Jakarta (ID): PT INDEKS Kelompok Gramedia

26. Robinson D, Perryman S, Hayday, S. 2004. The drivers of employee engagement. IES Report 408. Brighton: Institute for Employment Studies.

27. Sagiv L, Schwartz SH. 1995. Value priorities and readiness for outgroup social contact. Journal of Personality and Social Psychology. 69(3): 437-448.

28. Schaufeli WB, Bakker AB. 2004. Job demands, Job resources, and their relationship withburnout and engagement: a multi-sample study. Journal of Organizational Behavior. 25:293-315.

29. Schwartz SH. 1994. in Kim U, Triandis HC, Kagitc jbasi C, Choi SC, Yoon G. (Eds), Individualism and Collectivism: Theory, Application and Methods. Thousand Oaks: CA

30. Srinivasan V. 2012. Multi generation in the workforce: building collaboration. IIMB Management Review. 24:48-66.

31. Strauss W, Howe N. 2000. Generations. New York (US): Harper Perennial.

32. Twenge JM. 2006. Generation Me: Why Todays Young Americans Are More Confident, Assertive, Entitled-and More Miserable Than Ever Before. New York (US): Free Press.

33. Twenge JM, Campbell SM, Hoffman BJ, Lance CE. (2010), Generational differences in work values: leisure and extrinsic values increasing, social and intrinsic values decreasing. Journal of Management. 1: 1-26.

34. Veenhoven R. 2003. Hedonism and happiness. Journal of Happiness Studies.4(special issue on Art of living):437-457

35. Warburton DM, Sherwood N. (1996), Pleasure and Quality of life. Wiley: Chichester.

36. Wahjosumidjo. 1994. Kepemimpinan and Motivasi. Jakarta (ID): Ghalia Indonesia.

37. Wibowo. 2013. Perilaku dalam Organisasi. Jakarta (ID): Rajawali Pers.

38. Wigfield A, Eccles JS. 1994. Children's competence beliefs, achievement values, and general self-esteem. Journal of Early Adolescence. 14(2):107-139.

39. Wijayanto SH. 2008. Structural Equation Modeling. Yogyakarta (ID): Graha ilmu. 